\title{
Dietary intake of pregnant women and their infants in a poor black South African community
}

\author{
D Mostert, M Nutr \\ University of Limpopo, Sovenga
}

NP Steyn, PhD

Medical Research Council, Parowvallei (previously Univ. Limpopo)

NJ Temple, PhD

Centre for Science, Athabasca University, Canada

R Olwagen, BSc (Hons)

University of Limpopo, Sovenga

\section{Keywords:}

Natritional status, pregnancy. lactation

\section{Correspondence address:}

Dr NP Steyn

Medical Research Council

Chronic Diseases of Lifestyle Unit

P O Box 19070

Tygerberg

7505

Tel: $021-9380242$

Fax: 021-9335519

Email: nelia.stevn@mrc.ac.za

\section{Abstract: Curationis 28(4): 12-19}

The aims of this study were (i) to determine the dietary intake of women in a poor rural area during pregnancy and lactation, and (ii) to determine the nutritional status and dietary intake of their infants at age 6 months. We recruited 46 women, below 40 years old, in their 2 nd trimester of pregnancy. The subjects were living in a rural area of Limpopo Province. Their heights and weights were recorded, as were their diets during pregnancy and for the first 6 months after delivery. We also recorded weights, lengths, and dietary intake of the infants at 3 and 6 months after birth. The subjects were living in severe poverty: none had running water and almost all did their cooking over an open fire. None of the subjects smoked and only one consumed alcohol. The diets of the subjects consisted mainly of maize, brown bread, sweetened beverages (cold drink and tea), and small amounts of vegetables and chicken. The diets were adequate in protein but were marginal in energy and in dietary fibre, and may be deficient in numerous micronutrients, particularly calcium, iron, zinc, niacin, folate, and vitamins $\mathrm{A}, \mathrm{C}, \mathrm{E}$, and $\mathrm{B}_{6}$. This was seen during pregnancy and lactation. Blood analysis 6 months after birth revealed normal levels of vitamins $A$ and $E$ and an absence of anaemia. Body mass index (BMI) of the women was $23.9 \pm 5.3 \mathrm{~kg} / \mathrm{m} 2$ (mean $\pm \mathrm{SD}$ ) when measured 6 months after birth. Those above 25 years old had a higher BMI than did younger subjects ( 25.5 vs. 22.2; $\mathrm{p}=0.028$ ). Overall, $24 \%$ were overweight (BMI 25-30) while $9 \%$ were obese (BMI > 30). Most infants (93\%) were breastfed for at least 6 months but exclusive breastfeeding was only done by $65 \%$ of mothers. One-third of breastfed infants also received formula. The use of formula while breastfeeding was twice as common among mothers aged above 25 years ( $46 \%$ vs. 23\%). Early introduction of solid foods was very common in this group. Younger mothers introduced solids in the first month $(51 \%)$ more often compared with older mothers who tended to introduce solids at 2-3 months (64\%).

The most common solid food given was maize meal porridge (by $78 \%$ of all mothers). Mean BMI was low at birth $(<15)$, but this reached a normal value by 6 months. A significant fraction of the infants was underweight or short (i.e., stunted), based on being below the 3rd percentile compared with NCHS standards. Underweight was seen in $15 \%$ at birth, falling to $10 \%$ at 6 months, whereas $15 \%$ had a short length at birth, rising to $35 \%$ at 6 months. Underweight tended to be more common in boys and 
short length in girls. This study found that pregnant and lactating women had diets low in energy and micronutrients as reflected by the high prevalence of underweight at birth. Most infants were exclusively breastfed, but the benefit of this was offset by the early introduction of solid foods having a low energy and nutrient density. By 6 months, the prevalence of stunting had more than doubled.

\section{Opsomming}

Die doelwitte van hierdie studie is (i) om die dieetinname van vrouens tydens swangerskap en borsvoeding in ' $n$ arm landelike gebied vas te stel, en (ii) om die voedingstatus en dieetinname van hulle suigelinge op 6 maande vas te stel. Ons het 46 vrouens jonger as 40 jaar oud en in hulle $2^{\text {de }}$ trimester van swangerskap gewerf. Hierdie persone het in 'n landelike omgewing van Limpopo gewoon. Hulle lengte en gewig is bepaal, asook die dieet wat hulle gedurende swangerskap en die eerste 6 maande na die bevalling gevolg het. Die gewig, lengte en dieetinname van die suigelinge op 3 en 6 maande na geboorte is ook bepaal. Hierdie persone het in uiterste armoede geleef met geen lopende water tot hulle beskikking nie, en feitlik almal het 'n oop vuur vir kookdoeleindes gebruik. Geeneen het gerook nie, en slegs een het alkohol gebruik. Die diëte van die persone het hoofsaaklik bestaan uit mielies, bruin brood, sagte drankies, soos koeldrank en tee, en klein hoeveelhede groente en hoender. Die diëte het voldoende proteïen bevat, maar energie en dieetvesel het gegrens aan onvoldoende, terwyl heelwat mikrovoedingstowwe veral kalsium, yster, sink, niasien, foliensuur en vitamines $\mathrm{A}, \mathrm{C}, \mathrm{E}$, en $\mathrm{B}_{6}$ moontlik ontoereikend kon wees. Hierdie is waargeneem tydens swangerskap en laktasie. Ontleding van die bloed 6 maande na die bevalling het normale vitamine $\mathrm{A}$ en $\mathrm{E}$ vlakke getoon, en 'n afwesigheid van anemie. Liggaamsmassa-indeks (LMI) van die vrouens was $23.9 \pm 5.3 \mathrm{~kg} / \mathrm{m}^{2}(\mathrm{gem} \pm \mathrm{SA})$ gemeet op 6 maande na die bevalling. Diegene ouer as 25 jaar het ' $n$ hoër LMI gehad as die jonger persone ( 25.5 vs. $22.2 ; \mathrm{p}=0.028$ ). In totaal was $24 \%$ oorgewig (BMI $25-30$ ), terwyl 9\% vetsugtig was (BMI > 30). Meeste suigelinge( $93 \%$ ) is vir ten minste 6 maande geborsvoed, alhoewel $65 \%$ van die moeders uitluitlik borsvoeding gegee het. Een derde van die suigelinge het ook melkformule ontvang. Gelyktydige borsvoeding en gebruik van melkformule het twee keer so algemeen onder moeders ouer as 25 jaar voorgekom ( $46 \%$ vs. $23 \%$ ). Vroeë bekendstelling aan vaste voedsel het algemeen by hierdie groep voorgekom. Jonger moeders het vaste voedsel meer dikwels gedurende die $I^{\text {te }}$ maand $(51 \%)$ ingestel vergeleke met die ouer moeders wat geneig het om vaste voedsel op 2-3 maande (64\%) bekend te stel. Die algemeenste vaste voedsel wat gegee is was mieliemeelpap (deur $78 \%$ van al die moeders). Die gemiddelde LMI was laag by geboorte $(<15)$, maar het ' $n$ normale vlak teen 6 maande bereik. 'n Beduidende getal suigelinge was ondergewig of kort (i.e. belemmerde groei), deur onder die $3^{\text {te }}$ persentiel te val vergeleke met die NCHS standaarde. Ondergewig is waargeneem by $15 \%$ by geboorte, en het gedaal na $10 \%$ teen 6 maande. terwyl $15 \%$ kort van lengte by geboorte was wat teen 6 maande tot $35 \%$ gestyg het. Ondergewig het geneig om meer algemeen by seuns voor te kom en kortheid van lengte by meisies. Hierdie studie het gevind dat die swanger en lakterende vrouens diëte met lae energie en mikrovoedingstowwe gevolg het wat deur die hoë voorkoms van ondergewig by geboorte gereflekteer is. Meeste van die suigelinge is uitsluitlik geborsvoed, maar die voordeel hiervan is teen gewerk deur die vroeë bekendstelling van vaste voedsel met 'n lae energie en voedingsdigtheid. Teen 6 maande het die voorkoms van belemmerde groei meer as verdubbel.

\section{Introduction}

Several studies have furnished strong evidence that nutritional problems are frequently found in infants and children in South Africa. In particular stunting, as a manifestation of chronic malnutrition, is highly prevalent in children aged 1-3 years $(26 \%)$ and decreases to $13 \%$ at ages 7-9 years (Labadarios et al., 2000:194). The higher prevalence at ages 1-3 years was also found in a national anthropometric study of pre-school children in 1994 (SAVACG, 1995:106). Stunting was seen in $17 \%$ of those aged 6-11 months, and in $23 \%$ of children at both 1-2 years and 2-3 years of age. These findings indicate, therefore, that stunting was already evident in many children by 6 months and that this number increased from there until 3 years where after it decreased in school-going children.

The reasons for the high prevalence of stunting in children aged 1-3 years are not clear. However, it is postulated that this may be an outcome of poor diet during pregnancy, low birth weight of infants followed by an early and poor quality weaning diet. These factors have been described as determinants of poor nutritional status in other studies (Mamabolo et al., 2004:327: Steyn et al., 1993:10; Ladzani et al., 1998:63; Steyn, 2000:S1 1; Steyn et al., 1998:641).

To shed light upon this problem, information is needed concerning the diets of women during pregnancy and of their infants. Unfortunately, the diets of pregnant women living in poor deep rural areas in South Africa have not been documented and neither has the diet of their infants during the first months following birth. Since complementary foods are commonly introduced during the first 6 months of life (Steyn et al., 1993: 10: Steyn, 2000:S11), this period may be critical in the causation of later stunting.

In this cohort study, we followed a group of women who were in their second semester of pregnancy at the start of the study. We recorded their diets, both during pregnancy and lactation. We also studied the diets and growth of their infants over a period of 6 months to determine whether dietary practices during this period could be responsible for the high levels of stunting seen from 6 months onwards.

\section{Methods}

\section{Study area and participants}

The study subjects were 46 women, aged below 40 years, who were in their second trimester of pregnancy. They were randomly selected while visiting the Dikgale primary health-care clinic over a 3 -month period. The subjects were divided into two groups: one of women aged below 25 years and another group above 25 years old. The reason for this was to determine whether infant feeding practices differ by mother's age. The Dikgale clinic is in a rural village in the Limpopo Province, South Africa. This area borders Zimbabwe, Botswana, and Mozambique. The area is known to be one of the poorest in the country, with more that $50 \%$ of adults being unemployed (Health Systems Trust, 2003:430).

\section{Data collection and measurements}

The data were collected either by nurses at the clinic or by trained fieldworkers. who were recruited from the community and trained for the required tasks. 
Interviews were conducted in the subjects' language, namely Northern Sotho.

Heights of women (without shoes) were measured using a stadiometer. Weight was taken with minimal or light clothing using a portable, electronic scale. Lengths of the infants were measured with the infant lying down stretched on a flat surface, as described by Lee and Nieman (1993:122). Weights of the infants were measured using a portable, baby scale, with the infant naked. The height and weight of the infants were compared with the reference data of the National Center for Health Statistics (NCHS), which are based on a population of North American children and is recommended by the World Health Organization (WHO) for international use (NCHS et al., 1977:50). Blood pressure of the women was measured during pregnancy by trained nursing sisters using a mercury sphygmomanometer according to recommended procedures (American Heart Association, 1988:502A-508A). Blood samples were taken from infants and mothers who allowed this $(\mathrm{n}=20)$ and samples were analyzed for retinal and átocopherol (Milne \& Botnen, 1986:874). The small number of blood samples obtained is because this is difficult in rural areas; there are many superstitions associated with this as well as a fear of being found to be HIV positive.

Dietary intake of the pregnant women $\left(2^{\text {nd }}\right.$ and $3^{\text {rd }}$ trimesters) was obtained through a repeated 24-hour dietary recall method, one weekday and one weekend day, through personal interviews by the fieldworkers, as recommended (Nelson \& Bingham, 1997:143). The dietary intake of the lactating women was also obtained by means of repeated 24-hour recalls during post-natal visits. Dietary intake of the infants was obtained using a dietary history, through personal interviews by the fieldworkers with the mother or caregivers at 6 months after the birth of the baby. The fieldworkers recorded food quantities with the assistance of measuring cups and various food models. The dietary data were analysed for nutrient content using the Medical Research Council's Food Composition Tables (Langenhoven et al., 1991a) and Quantity Tables (Langenhoven et al., 1991b). Quality control checks was done on several occasions where different fieldworkers conducted interviews on the same subjects and the results were compared. No significant differences were seen when this was done.
A pilot study was undertaken with 12 pregnant women before the main study to test the questionnaires and the accuracy of the data collection by the fieldworkers.

\section{Statistical analysis}

Statistical analysis was performed using SPSS (Statistical Products and Service Solutions) software 11.0 for Windows. Student's t-test was used to compare mean body mass index (BMI) in the older and younger age groups. The effect of age on formula use while breastfeeding was analysed using the Chi-square test.

\section{Ethical approval}

Ethical approval was obtained from the Ethics Committee of the University of the North.

\section{Results}

\section{Observations during pregnancy}

Of the 46 women in the study, 22 (48\%) were aged between 13 and 24 ("younger group"), and 24 (52\%) were aged between 25 and 40 ("older group"). Most of the women $(88 \%)$ in the older group were married but only $12 \%$ of the younger group. Only one-third of the women had received an education beyond grade 9 .

\section{Table 1. Mean body mass index (BMI) of pregnant (4-6months) and lactating women attending the antenatal clinic at Dikgale}

\begin{tabular}{lllllll}
\hline Condition & Age categories & N & Mean BMI & SD & t-test & 95\% CI of the differences \\
\hline BMI Pregnancy & $13-24$ yrs & 22 & 25.47 & 3.27 & $0.033^{*}$ & $-6.492 ;-0.232$ \\
& $25-40$ yrs & 24 & 28.84 & 6.57 & & $-6.433 ; 10.290$ \\
\multirow{3}{*}{ BMI Lactation } & $13-24$ yrs & 22 & 22.20 & 2.98 & $0.028^{*}$ & $-6.249 ;-0.373$ \\
& $25-40$ yrs & 24 & 25.51 & 6.35 & & $-6.249 ;-0.373$
\end{tabular}

BMI at pregnancy

$<18.5$

$18.5-24.9$

All ages (\%)

0

39.1

$25-29.9$

43.5

$\geq 30$

BMI at lactation

$<18.5$

6.5

$18.5-24.9$

60.9

$25-29.9$

$\geq 30$
8.7

* Student t-test is significant at $\mathrm{p}<0.05$ 
Most of the fathers (59\%), however, had received an education at least to grade 11. The mothers were mostly $(63 \%)$ unemployed, while 33\% were students. With fathers, however, a much higher proportion $(52 \%)$ was employed, while $22 \%$ were unemployed and $26 \%$ were students. There was an average of 8.1 persons living in each household. The mothers had had an average of 2.1 previous pregnancies. Household income was mostly in the range R500R2000 per month (equivalent to about 170-680 US $\$ /$ month). None of the subjects had running water in their house and $94 \%$ did their cooking over an open fire.

No subjects were smokers, and no one reported being HIV positive although HIV/AIDS has a high prevalence in South Africa. Measurements at the clinic during pregnancy indicated that $17 \%$ had an elevated blood pressure (BP) (systolic BP
$>140 \mathrm{mmHg}$ and diastolic $\mathrm{BP}>90 \mathrm{mmHg}$ ). However, $37 \%$ had an elevation of either systolic or diastolic pressure.

BMI was determined at the time of the subjects' first visit to the clinic when they were about 4 - 6 months pregnant (Table 1). The mean BMI was $27.2 \pm 5.5 \mathrm{~kg} / \mathrm{m}^{2}$ (mean $\pm \mathrm{SD}$ ). It was higher in the older group than in the younger group (28.8 vs. $25.5 ; p=0.03)$. The proportion with a $\mathrm{BMI}=25$ was $61 \%$.

Analysis of the diets during pregnancy revealed a number of inadequacies (Table 2). The diets were marginal in energy and dietary fibre, though the content of protein was adequate. Intake of several minerals and vitamins was well below the Recommended Dietary Allowances (RDA) (Monsen, 1998; Food and Nutrition Board, 2001).

Most subjects (74\%) ate three meals daily during pregnancy, while $85 \%$ also had between-meal snacks. The most common snack was fruit, which was eaten by $76 \%$ of subjects.

The beverages most commonly consumed were cold drinks (94\%) and tea $(91 \%)$, followed by coffee ( $34 \%$ ); all contained sugar. Only one subject consumed an alcoholic beverage. Overall, the most common foods eaten were maize, brown bread, cold drink. and tea, followed by vegetables (most commonly spinach, pumpkin, carrots, cabbage, tomatoes, and onion), and chicken (usually once a week; typically the cheaper cuts such as gizzards, and feet). The most common type of food cravings were for fruit and vegetables, being reported by $67 \%$, followed by cold drinks $(20 \%)$, and milk and milk products (15\%).

\section{Observations during lactation}

When measured 6 months after birth. the BMI of the women was $23.9 \pm 5.3 \mathrm{~kg} / \mathrm{m}^{2}$ (mean $\pm \mathrm{SD}$ ). As during pregnancy the

Table 2. Nutrient intakes of the study population during pregnancy and lactation as analysed from repeated 24-hour recalls

\begin{tabular}{|c|c|c|c|c|c|c|c|}
\hline Nutrient & $\begin{array}{l}\text { Mean (SD) } \\
\text { intake in } \\
\text { pregnancy }\end{array}$ & $\begin{array}{c}95 \% \\
\text { Confidence } \\
\text { Intervals }\end{array}$ & $\begin{array}{c}\%<67 \% \text { of } \\
\text { RDA }^{*}\end{array}$ & $\begin{array}{l}\text { Mean (SD) } \\
\text { intake in } \\
\text { lactation }\end{array}$ & $\begin{array}{c}95 \% \\
\text { Confidence } \\
\text { Intervals }\end{array}$ & $\begin{array}{c}\%<67 \% \text { of } \\
\text { RDA }^{*}\end{array}$ & $\begin{array}{c}\text { Paired } \\
\text { difference } p \\
\text { value }\end{array}$ \\
\hline Energy (kJ) & $7760(2059)$ & $7149-8372$ & 26.1 & $8408(2488)$ & $7669-9147$ & 37.0 & 0.101 \\
\hline Carbohydrate & $306.2(88.0)$ & $280.0-332.3$ & & $348.4(113.0)$ & $314.8-381.9$ & & 0.018 \\
\hline Protein $(g)$ & $66.8(30.3)$ & $57.8-75.8$ & 23.9 & $73.9(43.0)$ & $61.1-86.7$ & 100.0 & 0.358 \\
\hline Fats $(g)$ & $55.5(47.3)$ & $41.4-69.5$ & & $48.4(24.8)$ & $41.0-55.7$ & & 0.321 \\
\hline Fibre (g) & $21.7(5.5)$ & $20.0-23.3$ & 43.5 & $22.9(8.3)$ & $20.5-25.4$ & 37.0 & 0.262 \\
\hline Calcium (mg) & $354.8(245.5)$ & $281.9-427.7$ & 89.1 & $254.2(163.0)$ & $205.8-302.6$ & 97.8 & 0.015 \\
\hline Iron (mg) & $9.6(4.3)$ & $8.3-10.9$ & 73.9 & $10.0(6.0)$ & $8.2-11.8$ & 76.1 & 0.691 \\
\hline Zinc (mg) & $8.1(4.3)$ & $6.8-9.4$ & 93.5 & $9.2(8.3)$ & $6.7-11.6$ & 97.8 & 0.433 \\
\hline Vitamin A (mg) & $574.2(428.4)$ & $446.9-701.4$ & 76.1 & $443.2(558.4)$ & $277.4-609.1$ & 80.4 & 0.169 \\
\hline Vitamin C (mg) & $34.7(26.6)$ & $13.8-24.6$ & 73.9 & $19.2(18.2)$ & $13.8-24.6$ & 97.8 & 0.003 \\
\hline Vitamin E & $5.6(3.2)$ & $4.7-6.6$ & 69.6 & $5.6(4.4)$ & $4.3-6.9$ & 78.3 & 0.979 \\
\hline Vitamin B6 (mg) & $0.87(0.39)$ & $0.75-0.98$ & 97.8 & $0.84(0.42)$ & $0.71-0.96$ & 89.1 & 0.706 \\
\hline Niacin (mg) & $10.94(4.97)$ & $9.5-12.4$ & 52.2 & $10.97(3.93)$ & $9.8-12.1$ & 78.3 & 0.973 \\
\hline Folate mg & $194.5(75.3)$ & $172.1-216.8$ & 100.0 & $175.8(72.7)$ & 154.2-197.4 & 100.0 & 0.201 \\
\hline
\end{tabular}

* RDA: Recommended dietary allowances are the 1989 American RDA, but values for vitamin $\mathrm{B}_{6}$, niacin, and folate are based on recent updates. 


\begin{tabular}{|c|c|c|c|}
\hline Parameter & Birth & 3 months & 6 months \\
\hline Weight $(\mathrm{kg})^{*}$ & $3.13 \pm 0.42$ & $5.94 \pm 0.90$ & $7.89 \pm 0.98$ \\
\hline 95\% Confidence intervals (Weight) & $2.98-3.27$ & $5.65-6.22$ & $7.58-8.20$ \\
\hline Length $(\mathrm{cm})^{*}$ & $48.6 \pm 4.9$ & $57.9 \pm 2.8$ & $63.7 \pm 2.7$ \\
\hline 95\% Confidence Intervals (Length) & $46.8-50.4$ & $57.0-58.8$ & $62.8-64.6$ \\
\hline Body mass index (BMI) $)^{\sharp}$ & $13.8 \pm 4.6$ & $17.7 \pm 2.6$ & $19.5 \pm 2.4$ \\
\hline 95\% Confidence Intervals (BMI) & $12.1-15.4$ & $16.9-18.6$ & $18.7-20.2$ \\
\hline \multicolumn{4}{|l|}{ All infants: } \\
\hline Underweight $(\%)^{*}$ & 14.7 & 11.7 & 9.6 \\
\hline Short length $(\%)^{*}$ & 14.9 & 21.7 & 34.6 \\
\hline Boys underweight $(\%)^{*}$ & 21.7 & 16.7 & 12.5 \\
\hline Boys short length $(\%)^{*}$ & 14.3 & 16.7 & 29.2 \\
\hline Girls underweight $(\%)^{*}$ & 7.7 & 6.7 & 6.7 \\
\hline Girls short length $(\%)^{*}$ & 15.4 & 26.7 & 40.0 \\
\hline
\end{tabular}

"Mean \pm SD

$*$ Percentage $<3^{\text {nd }}$ NCHS percentile

older group had a higher BMI (25.5 vs. 22.2; $\mathrm{p}=0.03$ ). The distribution of BMIs was underweight $7 \%$, normal weight $61 \%$, overweight $24 \%$, and obese $9 \%$ (Department of Health, 2002:247).

The dietary assessments were repeated during the period of lactation (Table 3). This was done at every clinic visit. Energy intake was higher than that seen during pregnancy. However, a similar pattern of sufficiency and inadequacy was seen for most nutrients. The most noteworthy changes were that intake of calcium, vitamin $A$, and vitamin $C$ was even more sub-optimal than before. This can be largely explained by the decreased consumption of milk, in the case of calcium, and of fruit, in the case of vitamin C. Blood samples, which were obtained from 20 subjects 6 months after birth, were analysed for vitamins $A$ and $E$. There was no indication of subnormal serum levels of either vitamin $(<1.05 \mathrm{mmol} / \mathrm{L}$ for vitamin $A$ or $<11.6 \mathrm{mmol} / \mathrm{L}$ for vitamin $\mathrm{E}$ ). The normal serum level of vitamin $A$ is consistent with the fact that the women had been given a supplement of the vitamin post-natally. Blood analysis also indicated that none of the subjects had anaemia, consistent with the fact that they had been given iron supplements at visits to the antenatal clinic.

\section{Infant Feeding}

Most infants (89\%) were cared for by their mother. The great majority of infants
(93\%) were breastfed for at least 6 months. However, exclusive breastfeeding was only done by $67 \%$ of mothers. Exclusive breastfeeding in this context means that no other milk was given, yet solids were often introduced from an early age. Onethird of breastfed infants also received formula. Use of formula while breastfeeding was twice as common among subjects in the older group (46\% vs. $23 \% ; \mathrm{p}=0.029$ ). Mothers cited the following reasons for giving formula milk in addition to breast milk: had to go back to school $(53 \%)$, own milk too weak or too little $(27 \%)$, and mothers' advice (13\%). Nearly half of infants (43\%) were given solid food within their first month, rising to $56 \%$ by 3 months. The most common solid food given was maize meal porridge (given by $78 \%$ of all mothers). Blood samples were obtained from 20 infants and analysed for serum levels of vitamins $A$ and $E$. Two of the infants had a marginal vitamin A deficiency $(<0.7 \mathrm{mmol} / \mathrm{L})$ but none had a sub-normal level of vitamin $E(<11.6 \mathrm{mmo} / \mathrm{L})$. As with the mothers the adequacy of the vitamin A blood levels reflects the supplements of the vitamin that the infants had been given.

The weights and lengths of the infants are shown in Table 4. Mean BMI was low at birth $(<15)$, but this reached a normal value by 6 months (Barker \& Godfrey, 2001:257; Doak et al., 2005: 131; Popkin et al., 1996:3009; WHO/UNICEF, 1990;
Dewey et al., 1992:1035; Hop et al., 2000:2684). A significant fraction of the infants was underweight or short (i.e. below the $3^{\text {rd }}$ percentile compared with NCHS standards) (NCHS, 1977:50). Underweight was seen in $15 \%$ at birth, falling to $10 \%$ at 6 months, whereas $15 \%$ had a short length at birth, rising to $35 \%$ at 6 months. Underweight tended to be more common in boys and short length in girls.

\section{Discussion}

This study, carried out in a poor rural community in the Limpopo Province of northern South Africa, presents a snapshot of the nutrition and health status of women during pregnancy and lactation. Some aspects of the findings were encouraging: based on self-reported information none of the women were smokers or HIV positive and only one consumed alcohol. These findings are consistent with the fact that there are strong taboos against smoking and alcohol consumption by women in this culture. However, these observations are overshadowed by serious dietary problems. The data reveal that the women typically consume a diet which is adequate in protein but marginal in energy and dietary fibre, yet may be deficient in numerous micronutrients, particularly calcium, iron, zinc, niacin, folate, and vitamins $\mathrm{A}, \mathrm{C}, \mathrm{E}$, and $\mathrm{B}_{h}$. This 


\begin{tabular}{|c|c|c|c|c|}
\hline \multirow{2}{*}{$\begin{array}{l}\text { Formula } \\
\text { categories }\end{array}$} & & \multicolumn{2}{|c|}{ Age categories } & \multirow[b]{2}{*}{ Total } \\
\hline & & 13-24 yrs & $25-40$ yrs & \\
\hline No formula & Count & 17 & 13 & 30 \\
\hline Exclusive breast & $\%$ in formula category & $56.7 \%$ & $43.3 \%$ & $100 \%$ \\
\hline feeding & $\%$ in age & $77.3 \%$ & $54.2 \%$ & $65.2 \%$ \\
\hline Formula and & Count & 5 & 11 & 16 \\
\hline \multirow[t]{2}{*}{ Breast } & $\%$ in formula & $31.3 \%$ & $68.8 \%$ & $100 \%$ \\
\hline & $\%$ in age & $22.7 \%$ & $45.8 \%$ & $34.8 \%$ \\
\hline \multirow[t]{3}{*}{ Total } & Count & 22 & 24 & 46 \\
\hline & $\%$ in formula category & $47.8 \%$ & $52.2 \%$ & $100 \%$ \\
\hline & $\%$ in age category & $100 \%$ & $100 \%$ & $100 \%$ \\
\hline
\end{tabular}

Chi-square $\mathrm{p}$ value $=0.029$ between age groups

was seen during both pregnancy and lactation.

Estimated energy intake was low during both pregnancy and lactation. Nevertheless, based on weights 6 months after birth, few of the women were underweight while $24 \%$ were overweight (BMI 25-30) and 9\% were obese (BMI $>30$ ). Overweight and obesity were more common in the older group. The low energy intake combined with slowly developing obesity indicates that the women have a low level of physical activity. It is well established that women in South Africa have a high prevalence of obesity by middle age (Department of Health, 2002:244).

Breastfeeding was seen to be the dominant feeding practice $193 \%$ of mothers were breastfeeding at 6 months). However, the benefits of this were partly neutralised by the fact that one-third of breastfed infants also received formula. A more serious problem is the early introduction of solid food, especially maize meal porridge. Half of infants were given solid food within their first month. Set against this nutritional background it is unsurprising that a significant fraction of the infants were underweight. A more serious problem was the prevalence of stunting: $35 \%$ had a length that was below the $3^{\text {tu }} \mathrm{NCHS}$ percentile at 6 months.

An earlier South African study reported high rates of stunting in infants aged 12 23 months (SAVACG, 1995:106). The rates were highest in rural areas, including Limpopo Province. These observations were confirmed on children aged $1-3$ years (as well as at ages 4-6 years) in the
National Food Consumption Survey (Labadarios et al., 2000:194). Our results may also be compared with another study carried out at about the same time in an adjacent community (Mamabolo et al., 2004:327). The latter study included more subjects (276) but only considered the post-natal period. In that study, similar observations were made concerning infant feeding practices. As seen in this study many infants had poor weight gain while a much more common problem was a high prevalence of stunting ( $36 \%$ had a length that was $<3^{\text {rd }}$ percentile of the NCHS median at 6 months and this continued unchanged until an age of one year). That study also revealed that factors predictive of a better growth pattern were electricity in the house, and a mother who was employed and was better educated. These three parameters are probably indicators of a lesser degree of poverty.

Low birth weight has been associated with adult development of obesity, cardiovascular disease, type 2 diabetes, and hypertension (Barker \& Godfrey, 2001:255). Much less is known concerning the long-term consequences of being short in infancy. However, since the nineties there have been a number of studies, which have shown an association between early stunting and overweight at a later stage, particularly in studies of populations undergoing the nutrition transition (Doak et al., 2005:129; Popkin et al., 1996:3009).

In agreement with our findings, other studies carried out in South Africa during the 1990s also reported high levels of breastfeeding as well as the early introduction of solid food (Steyn et al.. 1993:10; Ladzani et al., 1998:63: Steyn, 2000:S11; Steyn et al., 1998:641). The World Health Organization has recommended that infants be exclusively breastfed for the first 6 months (WHO/ UNICEF, 1990). This appears to lower the risk of stunting, especially among those living in poverty (Dewey et al., 1992:1041; Hop et al., 2000:2688; Villalpando \& Lopez-Alarcon, 2000:546). Accordingly, efforts should be made to educate mothers better in this regard. However, this is unlikely to be more than a partial answer to the problem of stunting; the clearly deficient diets of the women described in this study are also an urgent and important target for intervention. In this regard, poverty is the dominant obstacle to progress.

One approach to improve the nutrition and health status of the infants would be the expanded use of supplements, hoth for the women during pregnancy and lactation as well as for their infants. For example, it has been shown that giving vitamin A supplements to infants and young children can significantly reduce mortality rates (Rahmathullah. 2003:254; Ross, 2002:S2902; Herrera, 1992:267). The fact that fortification of maize and flour has been introduced since October 2003 should assist in alleviating this problem.

\section{Conclusion}

This study found that both pregnant and lactating women had a diet low in energy and micronutrients. This was reflected by the high prevalence of underweight at birth. The majority of infants were exclusively breastfed but the benefit of 
this was offset by the early introduction of solid foods. The prevalence of stunting was $15 \%$ at birth but increased to $35 \%$ at 6 months.

\section{Acknowledgment}

Ms Jean Fourie is acknowledged for technical and editorial assistance with the manuscript, as well as for the translation of the abstract into Afrikaans.

\section{References}

AMERICAN HEART ASSOCIATION

1988: Recommendations for human blood pressure determination by sphygmomanometers. Circulation. 77(2):501A-514A

BARKER, DJP \& GODFREY, KM 2001: Fetal nutrition and cardiovascular disease in adult life, in: Wilson, $T$ \& Temple, NJ (eds), Nutritional Health Strategies for Disease Prevention. Totowa, New Jersey: Humana Press, pp. 253-268.

DEPARTMENT OF HEALTH 2002: South Africa Health and Demographic Survey 1998: Full Report. Pretoria: Government Printers.

DEWEY, KG; HEINIG,MJ; NOMMSEN, LA; PEERSON, JM \& LONNERDAL, B 1992: Growth of breast-fed and formulafed infants from 0 to 18 months: the DARLING Study. Pediatrics. 89:10351041.

DOAK, CM; ADAIR, LS; BENTLEY,M; MONTEIRO, C \& POPKIN, BM 2005: The dual burden household and the nutrition transition paradox. International Joumal of Obesity. 29(1):129-136.

FOOD AND NUTRITION BOARD, 2001: Dietary Reference Intakes Proposed Definition of Dietary Fiber. Institute of Medicine, Washington DC: National Academy Press. Available: http://www.nap.edu [15 March 2005].

HEALTH SYSTEMS TRUST 2003: South African Health Review 2002. Durban: Health Systems Trust.

HERRERA,MG; NESTEI „P; EL AMIN. A; FAWZI, WW; MOHAMED, KA \& WELD, L 1992: Vitamin A supplementation and child survival. The Lancet. 340(8814):267-271.

HOP, LT; GROSS, R; GIAY, T;
SASTROAMIDJOJO,S; SCHULTINK, W \& LANG, NT 2000: Premature complementary feeding is associated with poorer growth of Vietnamese children. Journal Nutrition. 130:2683-2690.

LABADARIOS, D; STEYN, NP; MAUNDER, E; MACINTYRE, U; SWART, R; GERICKE, G; HUSSKISSON, J; DANNHAUSER, A; VORSTER, HH \& NESAMVUNI, AE 2000: The National Food Consumption Survey (NFCS): Children aged 1-9 years, South Africa, 1999. NFCS, Pretoria: Department of Health.

LADZANI, R; STEYN, NP \& NEL, JH 1998: Infant feeding practices of Pedi women in six semi-rural areas of the Northem Province. South African Journal of Epidemiology and Infection. 13:63-65.

LANGENHOVEN, ML; KRUGER, M; GOUWS, E \& FABER, M 1991a: MRC Food Composition Tables, $2^{\text {nd }}$ Edn, Parowvallei: Medical Research Council.

LANGENHOVEN, ML; KRUGER, M; GOUWS, E \& FABER, M 1991b: MRC Food Quantities Manual, $2^{\text {nd }}$ Edn, Parowvallei: Medical Research Council.

LEE, RD \& NIEMAN, DC 1993: Nutritional Assessment. Oxford: Brown \& Benchmark.

MAMABOLO, RL; ALBERTS, M; MBENYANE, GX; STEYN, NP; NTHANGENI,NG; DELEMARRE-VAN DE WAAL, HA \& LEVITT, NS 2004: Feeding practices and growth of infants from birth to 12 months in the central region of the Limpopo Province of South Africa. Nutrition. 20(3):327-333.

MILNE, DB \& BOTNEN, J 1986: Retinol, alpha-tocopherol, lycopene and alpha- and beta-carotene simultaneously determined in plasma by isocratic liquid chromatography. Clinical Chemistry. 32:874-876.

MONSEN, ER 1989: The 10th edition of the Recommended Dietary Allowances: what's new in the 1989 RDAs? Journal of the American Diet Association. 89(12):1748-1752.

NATIONAL CENTRE FOR HEALTH STATISTICS (NCHS), 1977. NCHS growth curves for children. Birth to 18 years. DHEW publication PHS 78-1650. Hyattsville, Maryland: US Department of
Health, Education and Welfare

NELSON, M \& BINGHAM,SA 1997: Assessment of food consumption and nutrient intake, in: Margetts, BM \& Nelson, $M$ (eds), Design Concepts in Nutritional Epidemiology, $2^{\text {ind }}$ Edn, Oxford: Oxford Medical Publications. pp 123-169.

POPKIN, BM; RICHARDS, MK \& MONTEIRO, CA 1996: Stunting is associated with overweight in children of four nations that are undergoing the nutrition transition. Journal of Nutrition. 26:3009-3016.

RAHMATHULLAH,L; TIELSCH,JM; THULASIRAJ, RD; KATZ, J; COLES, C; DEVI, S; JOHN, R; PRAKASH, K; SADANAND, AV; EDWIN, N \& KAMARAJ, C 2003: Impact of supplementing newborn infants with vitamin $A$ on early infant mortality: community based randomised trial in southern India. British Medical Journal. 327(7409):254-259.

ROSS, DA 2002: Recommendations for vitamin A supplementation. Journal Nutrition. 132(9 Suppl):2902S-2906S.

SOUTH AFRICAN VITAMIN A CONSULTATIVE GROUP (SAVACG) 1995: Children aged 6 - 71 months in South Africa, 1994: Their anthropometric, vitamin $A$, iron and immunization coverage status. Stellenbosch: University of Stellenbosch.

STEYN, NP 2000: A South African perspective on preschool nutrition. South African Journal of Clinical Nutrition. 13:S9-S13.

STEYN, NP; BADENHORST, CJ; NEL, JH \& LADZANI, R 1993: Breast-feeding and weaning practices of Pedi mothers and the dietary intakes of their preschool children. South African Journal of Food. Science and Nutrition. 5:10-13.

STEYN, NP; NEL, JE; KUNNEKE, E; TICHELAAR, HY; OELOFSE, A; PRINSLOO,JF \& BENADÉ, AJS 1998: Differences between underweight and normal weight rural preschool children in terms of infant feeding practices and socio-economic factors. South African Medical Journal. 88:641-646.

VILLALPANDO, S \& LOPEZALARCON, $M$ 2000: Growth faltering is prevented by breast-feeding in 
underprivileged infants from Mexico City. Journal of Nutrition. 130:546-552.

WHO/UNICEF 1990: Protection, promotion and support of breastfeeding. Geneva: World Health Organization. 